\title{
PENGARUH KONSENTRASI GULA PADA PEMBUATAN MAHKOTA DEWA (Phaleria Macrocamps) INSTANT
}

\author{
Ernawati, S.TP ${ }^{(1)}$ dan Retti Ninsix, S.TP., MP ${ }^{(2)}$ \\ ${ }^{(1)}$ Alumni Teknologi Pangan Faperta UNISI \\ ${ }^{(2)}$ Dosen Teknologi Pangan Faperta UNISI
}

\begin{abstract}
Abstrak
Penelitian pengaruh konsentrasi gula pada proses pembuatan mahkota dewa (Phaleria macrocarpa) instan terhadap mutu yang dihasilkan. Tujuan penelitian untuk mengetahui konsentrasi gula pada proses pembuatan mahkota dewa instan terhadap mutu yang dihasilkan, untuk mengetahui proses pembuatan mahkota dewa yang dihasilkan dan untuk mengetahui hasil organoleptik ( rasa, aroma, warna dan tekstur ) mahkota dewa yang dihasilkan. Penelitian ini menggunakan Rancangan Acak Lengkap ( RAL) yang terdiri lima perlakuan yaitu G 1 : $60 \%$ gula dalam $500 \mathrm{ml}$ air rebusan mahkota dewa, G 1:60\% gula dalam $500 \mathrm{ml}$ air rebusan mahkota dewa, G2 : $65 \%$ gula dalam $500 \mathrm{ml}$ air rebusan ahkota dewa, G3 : $70 \%$ gula dalam $500 \mathrm{ml}$ air rebusan mahkota dewa, $04: 75$ $\%$ gula dalam $500 \mathrm{ml}$ air rebusan mahkota dewa, Gl : $80 \%$ gula dalam $500 \mathrm{ml}$ air rebusan mahkota dewa.

Hasil terbaik dari analisa kimia mahkota dewa instan yang meliputi kadar air terdapat pada perlakuan G4 $(75 \%$ gula dalam $500 \mathrm{ml}$ air rebusan mahkota dewa) yaitu $3.25 \%$, kadar abu terdapat pada perlakuan 03 (70 \% gula dalam 500 $\mathrm{ml}$ air rebusan mahkota dewa yaitu $0.59 \%$ dan kadar sukrosa terdapat pada perlakuan G3 (70\% gula dalam $500 \mathrm{ml}$ air rebusan mahkota dewa yaitu $74.66 \%$. Hasil terbaik untuk uji organoleptik yang meliputi aroma terdapat pada perlakuan G5 $(75 \%$ gula dalam $500 \mathrm{ml}$ air rebusanmahkota dewa) yaitu $3.1 \%$ dan tekstur terdapat pada perlakuan G5 (75\% gula dalam $500 \mathrm{ml}$ air rebusan mahkota dewa) yaitu $3.4 \%$.
\end{abstract}

Kata Kunci : Gula, Mahkota Dewa

\section{PENDAHULUAN}

Mahkota dewa adalah bahan alam (khususnya tumbuh-tumbuhan) yang merupakan keanekaragaman hayati yang masih sangat sedikit menjadi subjek penelitian ilmiah di Indonesia, padahal Indonesia merupakan negara yang memiliki kekayaan keanekaragaman hayati terbesar di dunia dengan lebih kurang 40.000 jenis tumbuhan, dari jumlah tersebut bam sekitar 940 spesies yang diketahui berkhasiat terapautik (mengobati) melalui penelitian ilmiah hanya sekitar 180 spesies diantaranya yang telah dimanfaatkan dalam obat tradisional oleh industri obat Indonesia (Lisdawati, 2002).

Mahkota dewa (Phaleria macrocarpa) merupakan salah satu jenis tanaman obat asli Indonesia yang berasal dari daerah Irian Jaya (Papua) dan tersebar luas di seluruh Nusantara. Mahkota dewa tergolong tumbuhan 
yang mampu hidup di berbagai kondisi, dari dataran rendah sampai dataran tinggi. Pohon ini mampu hidup pada ketinggian 1200 meter dari permukaan laut (dpl), dimana teknik budidayanya relatif mudah karena dapat ditanam secara monokultur maupun tumpang sari dan akan tumbuh dengan baik jika ditanam di tanah gembur dengan kandungan bahan organik yang tinggi.

Buah mahkota dewa mempunyai peranan penting dalam dunia kesehatan, tetapi masalah pemakaian sebagai tanaman obat belum banyak diketahui, hal ini disebabkan karena masih terbatasnya pembuktianpembuktian secara ilmiah dan hanya bersifat pengalaman. Berdasarkan penelitian-penelitian sebelumnya, diketahui bahwa mahkota dewa kaya akan kandungan kimia. Menurut Sumastuti (2005), Mahkota dewa mengandung zat antihistamin yang merupakan penangkal alergi dan juga berperan seperti oxytosin atau sintosin yang dapat memacu kerja otot rahim sehingga persalinan berlangsung dengan lancar.

Melihat begitu banyaknya kandungan kimia yang terdapat dalam mahkota dewa maka perlu adanya penganekaragaman dalam pengolahan, untuk itu prospek tersebut harus didukung teknik budidaya yang baik sehingga menghasilkan produksi yang relatif tinggi. Hermanto (2005) menyatakan bahwa, apabila buah tidak segera ditangani setelah panen maka akan dapat mempengaruhi keoptimalan khasiatnya, untuk mengatasinya perlu pengolahan lanjutan, dimana dengan cara penggolahan menjadi berbagai macam produk maka daya simpan menjadi lebih lama dan jangkauan pemasaran lebih luas.
Pengolahan mahkota dewa sebagai minuman fungsional kurang maksimal, sehingga animo konsumen untuk mengkonsumsinya sangat kurang, padahal khasiatnya sangat besar, selama ini mahkota dewa dikonsumsi dari air seduhan buah mahkota dewa kering yang rasanya pahit, sehingga diperlukan penelitian dan pengembangan produk bam dari mahkota dewa untuk menghasilkan produk yang dapat mengurangi rasa pahit dan praktis dikonsumsi

Selain itu dimaksudkan agar mahkota dewa itu mempunyai manfaat bagi kesehatan dan juga mudah diperoleh sebagai obat dengan cara biasanya dikonsumsi dalam bentuk rebusan setelah dilakukan pengeringan. Dengan berkembangnya teknologi pengolahan pangan mahkota dewa menjadi mahkota dewa instan menjadi serbuk minuman yang menyehatkan.

Berdasarkan hal tersebut maka penulis melaksanakan penelitian dengan judul" Pengaruh Konsentrasi Gula Pada Proses Pembuatan Mahkota Dewa (Phaleria macrocarpa) Instan Terhadap Mutu yang Dihasilkan".

Mahkota dewa sebagai salah satu jenis tanaman obat-obatan yang memiliki manfaat besar bagi kesehatan. Kurangnya pemanfaatan menyebabkan tanaman ini kurang dikenal. Salah satu pemanfaatan mahkota dewa yang dilakukan pada penelitian ini yakni mengolahnya menjadi mahkota dewa instan. Dalam pengolahan mahkota dewa menjadi mahkota dewa instan belum diketahui berapa perbandingan air mahkota dewa rebusan dengan gula yang baik dan serta hasil organoleptik mahkota dewa instan yang dihasilkan dapat diterima oleh konsumen bila diproduksi nantinya. 


\section{Tujuan Penelitian}

Tujuan dari penelitian ini adalah :

1. Untuk mengetahui konsentrasi gula pada proses pembuatan mahkota dewa instan terhadap mutu yang di hasilkan.

2. Untuk mengetahui proses pembuatan mahkota dewa instan yang dihasilkan.

3. Untuk mengetahui hasil organoleptik (rasa, aroma, warna dan tekstur) mahkota dewa instan yang dihasilkan.

\section{Manfaat Penelitian}

1. Sebagai sumber informasi dan pengetahuan pada pembuatan mahkota dewa instan yang dihasilkan.

2. Memberikan pengetahuan kepada masyarakat tentang pengolahan mahkota dewa dengan campuran gula pasir.

3. Diversifisikasi produk olahan mahkota dewa dengan campuran gula.

\section{Bahan}

Bahan utama yang digunakan dalam penelitian ini adalah buah mahkota dewa yang sudah matang ditandai dengan perubahan warna dari hijau menjadi merah marun yang diperoleh dari Desa Bagan Jaya Kecamatan Enok Kabupaten Indragiri Hilir Provinsi Riau, gula pasir dan air.

Bahan-bahan kimia yang digunakan untuk analisa yaitu CUS04, Aquades, $\mathrm{NaOH} 1 \mathrm{~N}, \mathrm{KI} 10 \%$, HCI 0,1 $\mathrm{N}, \mathrm{NaOH} 4 \mathrm{~N}$, dan $\mathrm{H}_{2} \mathrm{~S} 0425 \%$.

\section{Alat \\ Alat-alat yang digunakan dalam penelitian ini adalah bak, ember, keranjang plastik, pisau stainless steel, alat pengukuran volume (gelas ukur),}

pengukur berat (timbangan), penyaring/kain saring, kompor, wajan/penggorengan stainless steel, pengaduk stainless steel, ayakan, oven, panci stainless steel, pengemas plastik, blender dan sendok pengaduk.

\section{Metode Penelitian}

Penelitian ini dilaksanakan dengan menggunakan Rancangan Acak Lengkap (RAL) yang terdiri dari lima perlakuan konsentrasi gula dan $3 \mathrm{x}$ ulangan sehingga diperoleh 15 unit percobaan. Adapun perlakuan yang digunakan adalah sebagai berikut:

$\mathrm{G} 1$ : $60 \%$ gula dalam $500 \mathrm{ml}$ air rebusan mahkota dewa

G2 : $65 \%$ gula dalam $500 \mathrm{ml}$ air rebusan mahkota dewa

G3 : 70\% gula dalarn $500 \mathrm{ml}$ air rebusan mahkota dewa

G4 : $75 \%$ gula dalam $500 \mathrm{ml}$ air rebusan mahkota dewa

G5 : $80 \%$ gula dalam $500 \mathrm{ml}$ air rebusan mahkota dewa

Data yang diperoleh dari hasil penelitian dianalisis secara statistik dengan $\mathrm{F}$ hitung sarna atau lebih besar dari $\mathrm{F}$ Table maka dilakukan uji lanjut Tukey pada taraf $5 \%$ untuk membandingkan tiap perlakuan.

\section{HASIL DAN PEMBAHASAN}

Proses pembuatan atau pengolahan sebuah produk pangan ada beberapa hal yang perlu diperhatikan agar kualitas mutu produk tersebut terjamin, seperti kualitas mutu secara organoleptik, Mutu kimia terhadap mahkota dewa instan yang dianalisis terdiri dari kadar air, kadar abu dan kadar gula. Sedangkan pada mutu organoleptik yang dinilai yaitu : warna, aroma, tekstur dan rasa pada mahkota dewa instan yang dihasilkan. 
Kadar Air

Kandungan air suatu bahan
pangan sangat penting untuk
diketahui utamanya bila bahan pangan
tersebut akan diolah menjadi produk
yang akan dikonsumsi. Hasil analisa
kandungan air dapat menjadi bahan

informasi dan acuan dalam melakukan penanganan pasca pan en secara tepat sehingga dapat menghasilkan produk olahan yang berkualitas tinggi. Analisa kadar air yang diperoleh dari penelitian pembuatan mahkota dewa instan dapat dilihat pada Tabel 1.

Tabel 1. Pengaruh Konsentrasi Gula pada Proses Pembuatan Mahkota Dewa (Phuleria macrocarpa) Instan terhadap Kadar Air Mahkota Dewa Instan yang Dihasilkan

\begin{tabular}{|c|c|}
\hline Perlakuan & Rata-rata (\%) \\
\hline G4 (75\% gula dalam 500 ml air rebusan mahkota dewa) & 3.25 \\
G1 (60\% gula dalam 500 ml air rebusan mahkota dewa) & 2.10 \\
G5 (80\% gula dalam 500 ml air rebusan mahkota dewa) & 2.04 \\
G3 (70\% gula dalam 500 ml air rebusan mahkota dewa) & 1.91 \\
G2 (65\% gula dalam 500 ml air rebusan mahkota dewa) & 1.82 \\
\hline
\end{tabular}

Berdasarkan Tabel 4 dapat dilihat bahwa kadar air mahkota dewa instan persentase tertinggi terdapat pada perlakuan G4: $(75 \%$ gula dalam $500 \mathrm{ml}$ air rebusan mahkota dewa) yaitu $3.25 \%$ sedangkan hasil terendah dapat dilihat pada perlakuan $\mathrm{G} 2$ : (65\% gula dalam $500 \mathrm{ml}$ air rebusan mahkota dewa) yaitu $1.82 \%$.

Analisa sidik ragam perlakuan terhadap air : mahkota dewa instan menunjukkan bahwa hasil yang diperoleh berbeda tidak nyata. Hal ini berdasarkan Tabel 3a menunjukkan nilai $\mathrm{F}$ hitung 0.83 lebih kecil dari pada nilai $F$ Tabel 5\% sebesar 3.48 sehingga yang diperoleh berbeda tidak nyata, dari hasil penelitian pengaruh konsentrasi gula pada proses pembuatan mahkota dewa instan terhadap mutu yang dihasilkan. Hal ini menunjukan bahwa konsentrasi gula yang berbeda dan air rebusan mahkota dewa dengan ukuran yang saran menghasilkan rata-rata berat konstan kadar air masing-masing sampel tidak jauh beda. Tinggi rendahnya kadar air pada perlakuan diduga juga di pengaruhi oleh faktor transfortasi dan waktu belum di lakukannya analisa. Selama perjalanan dapat di mempengaruhi kadar air dari produk rnahkota dewa instan karena mungkin saja terjadi penguapan atau penyerapan air, sehingga peningkatan konsentrasi gula dapat menurunkan kadar air.

Proses pemanasan atau pemasakan yang dilakukan pada penelitian ini dengan suhu di atas 65 ${ }^{\circ} \mathrm{C}$ dengan lama pemanasan atau pemasakan 30 menit.

Sukrosa mampu mengikat air, sehingga menyebabkan kadar air pada produk semakin keeil karena semakin besar persentase penambahan sukrosa pada proses pembuatan mahkota dewa instan ini. Perbedaan jumlah kadar sukrosa yang dihasilkan pada produk akhir dari mahkota dewa instan ini membuktikan bahwa semakin tinggi konsentrasi gula, maka 
semakin besar jumlah air yang tertarik keluar

Berdasarkan SNI 01-4320-1996

mahkota dewa instan adalah ramuan instan yang berbahan baku air rebusan mahkota dewa yang dicampurkan dengan gula yang dihasilkan berbentuk serbuk minuman yang dikeringkan.

Kadar air sangat berpengaruh terhadap mutu bahan pangan, dan hal ini merupakan salah satu sebab mengapa di dalam pangan, air tersebut sering dikurangi atau dikeluarkan dengan cara penguapan atau pengentalan atau pengeringan. Kandungan air sangat berpengaruh terhadap konsistensi bahan pangan (Winamo, 2002).

\section{Kadar Abu}

Pengujian atau analisis kadar abu yang dilakukan pada penelitian ini dimaksudkan untuk mengetahui seberapa besar atau sebanyak kandungan abu sampel mahkota dewa instan. Dimana abu merupakan sisa hasil pembakaran yang dilakukan pada bahan pangan. Hasil analisa kadar abu pada sampel mahkota dewa instan dapat dilihat pada Tabel 2.

Tabel 2. Pengaruh Konsentrasi Gula pada Proses Pembuatan Mahkota Dewa (Phaleria macrocarpa) Instan terhadap Kadar Abu Mahkora Dewa Instan yang Dihasilkan

\begin{tabular}{|c|c|}
\hline Perlakuan & Rata-rata (\%) \\
\hline G3 (70\% gula dalam 500 ml air rebusan mahkota dewa) & 0.59 \\
G2 (65\% gula dalam 500 ml air rebusan mahkota dewa) & 0.48 \\
G1 (60\% gula dalam 500 ml air rebusan mahkota dewa) & 0.42 \\
G4 (75\% gula dalam 500 ml air rebusan mahkota dewa) & 0.34 \\
G5 (80\% gula dalam 500 ml air rebusan mahkota dewa) & 0.32 \\
\hline
\end{tabular}

Berdasarkan Tabel 2, dapat dilihat bahwa kadar abu rnahkota dewa instan persentase tertinggi terdapat pada perlakuan G3 : $(70 \%$ gula dalam $500 \mathrm{ml}$ air rebusan mahkota dewa) yaitu $0.59 \%$ sedangkan hasil terendah dapat dilihat pada perlakuan G5 : $(80 \%$ gula dalam $500 \mathrm{ml}$ air rebusan mahkota dewa) yaitu $0.32 \%$. Tinggi rendahnya kadar abu dari mahkota dewa instan dipengaruhi oleh kandungan kadar air dari tepung yang dihasilkan, semakin tinggi kandungan kadar air mahkota dewa instan maka kadar abu dari serbuk minuman akan rendah. Dari hasil analisa kadar abu mahkota dewa instan tingginya kadar air pada perlakuan G4 (75 \% gula dalam $500 \mathrm{ml}$ air rebusan mahkota dewa) yaitu $0,59 \%$ tidak di ikuti dengan rendahnya kadar air, hal ini disebabkan oleh beberpa faktor di antaranya waktu selama perjalanan dapat mempengaruhi kadar abu dari produk mahkota dewa instan karena mungkin saja terjadi penguapan atau penyerapan air, sehingga akan mempengaruhi kadar abu.

Abu merupakan mineralmineral yang masih terdapat di dalam mahkota dewa yang merupakan sisa pembakaran bahan organik. Menurut Berlian (1997), formula yang diolah dengan suhu tinggi telah 
menurunkan kadar air produk, sehingga kandungan bahan padatan seperti abu dan mineral meningkat. Menurut Sudarmadji et al, (1997), abu adalah zat anorganik sisa hasil pembakaran yang ada pada bahan pangan.

Analisa sidik ragam perlakuan terhadap kadar abu mahkota dewa instan menunjukkan bahwa hasil yang diperoleh tidak berbeda nyata. Menurut Berlina (1997) formula yang diolah dengan suhu tinggi telah menurunkan kadar air produk sehingga kandungan bahan padatan seperti abu dan mineral meningkat.

Menurut Winamo (2002) kadar abu merupakan zat organik ataupun unsur- unsur mineral yang terdapat dari sisa pembakaran pada suatu bahan makanan, menurut Berlina (1997) formula yang diolah dengan suhu tinggi telah menurunkan kadar air produk, sehingga kandungan bahan padatan seperti abu dan mineral meningkat. Kadar abu dari semua perlakuan memenuhi standar SNI 01 4320-1996 yaitu maksimal 1,5\% dan dari penelitian yang dilakukan bahwa kadar abu sudah dapat diterima yaitu kadar abu berkisar antara 0,32\% . $0,59 \%$

\section{Kadar Sukrosa}

Bahan pangan memiliki kandungan atau komposisi gula yang berbeda-beda. Gula merupakan paktor penting untuk sebuah produk pangan, dimana kandungan gula pada produk pangan dapat memberi kesan bagus terhadap penilaian konsumen. Beberapa metode pengujian yang dilakukan untuk menentukan berapa total kandungan gula suatu bahan pangan, salah satunya adalah penguji total gula metode fenol (Sudarmadji, dkk, 1997). Hasil analisa total gula mahkota dewa instan dapat dilihat pada Tabel 3.

Tabel 3. Pengaruh Konsentrasi Gula pada Proses Pembuatan Mahkota Dewa (Phaleria macrocarpa) Instan terhadap Kadar Sukrosa Mahkota Dewa Instan yang Dihasilkan

\begin{tabular}{|c|c|}
\hline Perlakuan & Rata-rata $(\%)$ \\
\hline G3 (70\% gula dalam 500 ml air rebusan mahkota dewa) & 74.66 \\
G4 (75\% gula dalam 500 ml air rebusan mahkota dewa) & 73.52 \\
G2 (65\% gula dalam 500 ml air rebusan mahkota dewa) & 73.29 \\
G5 (80\% gula dalam 500 ml air rebusan mahkota dewa) & 72.88 \\
G1 (60\% gula dalam 500 ml air rebusan mahkota dewa) & 72.68 \\
\hline
\end{tabular}

Berdasarkan Tabel 3, dapat dilihat bahwa kadar sukrosa mahkota dewa instan persentase rata-rata tertinggi terdapat pada perlakuan G3 : (70\% gula dalam $500 \mathrm{ml}$ air rebusan mahkota dewa) yaitu $74.66 \%$ sedangkan hasil rata-rata terendah dapat dilihat pada perlakuan G 1 : (60\% gula dalam $500 \mathrm{ml}$ air rebusan mahkota dewa) yaitu $72.68 \%$. Tinggi rendahnya kadar sukrosa pada perlakuan juga di pengaruhi oleh faktor transfortasi dan waktu belum di lakukannya analisis. Waktu selama perjalanan dapat di mempengaruhi kadar sukrosa dari produk mahkota dewa instan karena mungkin saja terjadi penguapan atau penyerapan air, sehingga peningkatan 
konsentrasi gula tidak menurunkan kadar air.

Hal ini disebabkan sukrosa mudah bereaksi oleh panas pada proses pemasakan, sehingga sebagian sukrosa akan terurai menjadi glukosa dan fruktosa atau yang disebut gula invert. Hal ini diperkuat oleh Desrosier (1988) yang mengungkapkan bahwa penentuan kadar gula total adalah penetapan kadar gula sebelum inversi atau gula pereduksi dan pengukuran gula setelah inversi (sakarosa). Selama pendidihan larutan sakarosa dengan adanya asam akan terjadi proses hidrolisis menghasilkan gula reduksi (dekstrosa dan lelulosa). Sakarosa diubah menjadi gula reduksi dan hasilnya dikenal sebagai gula inversi. Kecepatan inversi dipengaruhi oleh suhu, waktu pemanasan dan nilai $\mathrm{pH}$ dari larutan. Selama pemanasan larutan sukrosa menjadi glukosa dan fruktosa akibat pengaruh pengaruh panas dan asam yang akan meningkatkan kelarutan sukrosa. Dengan meningkatnya kelarutan sukrosa maka akan meningkat kadar gula totalnya.

Analisa sidik ragam perlakuan terhadap sukrosa mahkota dewa instan menunjukkan bahwa hasil yang diperoleh tidak berbeda nyata. Hasil ini menunjukkan bahwa kadar gula mahkota dewa instan sesuai dengan standar mutu minuman serbuk yakni sebesar $85.0 \%$. Hal ini sesuai dengan pernyataan Badan Standarisasi Nasional (1996), bahwa jumlah gula yang diizinkan untuk minuman serbuk tradisional sebesar $85.0 \%$ dan tercantum didalam Tabel SNI mutu serbuk minuman tradisional 01-43201996.

Gula dalam produk pangan memiliki peranan penting karena fungsinya yang beraneka ragam, yaitu sebagai pemanis, pembentuk tekstur, pengawet, pembentuk cita rasa, dan sebagai bahan pengisi. Beberapa monosakarida dan oligosakarida mempunyai rasa manis sehingga sering kali digunakan sebagai bahan pemanis, yang paling sering digunakan adalah sukrosa, glukosa, dan dektrosa (Deman, 1997).

\section{KESIMPULAN}

Kesimpulan yang dicapai pada penelitian ini adalah sebagai berikut :

1. Pengaruh konsentrasi gula pada proses pembuatan mahkota dewa (Phalaria macrocarpa) instan terhadap mutu yang dihasilkan memberi pengaruh nyata terhadap kadar air, kadar abu, kadar gula, tekstur, aroma, tetapi tidak memberikan pengaruh yang nyata untuk uji organoleptik yang meliputi warna dan rasa menurut uji Tukey pada taraf nyata $5 \%$.

2. Analisa kimia mahkota dewa instan yang diperoleh pada penelitian ini yaitu : kadar air tertinggi $(3.25 \%)$ pada perlakuan G5 dan terendah (1.82 \%) pada perlakuan 02, kadar abu tertinggi $(0.59 \%)$ pada perlakuan 03 dan terendah $(0.32 \%)$ pada perlakuan G5, kadar sukrosa tertinggi $(74.66 \%)$ pada perlakuan G3 dan terendah (72.68 \%) pada perlakuan Gl.

3. Hasil terbaik dad analisa kimia mahkota dewa instan yang meliputi kadar air terdapat pada perlakuan $04 \quad(75 \%$ gula dalam $500 \mathrm{ml}$ air rebusan mahkota dewa) yaitu $3.25 \%$, kadar abu terdapat pada perlakuan G3 (70\% gula dalam $500 \mathrm{ml}$ air rebusan mahkota dewa yaitu $0.59 \%$ dan kadar sukrosa terdapat pada perlakuan 03 ( $70 \%$ gula dalam $500 \mathrm{ml}$ air rebusan mahkota dewa yaitu 74.66 $\%$ 


\section{SARAN}

Perlu melakukan penelitian Iebih Ianjut mengenai analisa mikroba, pengaruh pengemasan dan lama penyimpanan terhadap kualitas produk mahkota dewa instan.

\section{DAFTAR PUSTAKA}

Adawiyah R. 2007. Pengolahan dan Pengawetan Ikan. Bumi Aksara, Jakarta.

Anonim. 2009. http://Penggolongangula. dahlanFrumwordpress.com. diakses 02 oktober 2009.

Anonim. 1999. Universitas Tanaman Obat Indonesia edisi $\mathrm{V}$. Jakarta: Depertemen kesehatan badan penelitian dan pengembangan kesehatan.

Badan Standarisasi Nasinal. 1996. Syarat Mutu Serbuk Minuman Tradisional Menurut

Standar Nasinal Indonesia 01-43201996.

Baliwati, Y.F., A Khomsan dan C.M Dwiraiani, 2004. Pengantar Pangan dan Gizi. Penebar Swadaya, jakarta.

Bernasconi, G.,H. Grestar, H. Hauser, H. Satu ble E. Schneiter, 2005. Teknologi Kimia bagian 2 terjemahan L, Hadoyo. Pradnya Paramita, Jakarta.

Buckle, K.A., Edwards, R.A., Fleet, G,H., Wooton, M. 1987. Ilmu Pangan. Universitas Indonesia. Jakarta.

Berlian. 1997. Pemanfaatan Ampas Kelapa Untuk Makanan Rendah Kalori Jurnal Penelitian Tanaman Industry. Bogor.

Deman IM. 1997. Kimia Makanan. Institut Terhadap Pertumbuhan Bibit Mahkota Dewa-Phaleria macrocarpa, di Polibag, Jumal Akta Agrosia (7) $2: 72-75$.
Djumidi . 1999. Inventaris Tanaman Obat Indonesia. Ed $\mathrm{Ke}-5$ Jakarta : Balai Pengembangan Kesehatan Depertemen Kesehatan.

Desrosier, W. 1988. Teknologi Pengawetan Pangan, di terjemahkan oleh Muchi Muljoharjo, Penerbit Universitas Indonesia, Jakarta.

Harmanto, N. 2002. Sehat Dengan Ramuan Tradisional Mahkota Dewa. Tengerang PT.Agromedia Pustaka, Jakarta. 2003. Conquering Disease in Unison with Mahkota Dewa. Phaleria Macroocarpa. First editon. PT. Mahkota Dewa Indonesia, Jakarta .

Hardiman, 1991. Kumpulan Handout : Tekstur Pangan, Penerbit Pusat Antara Universitas Pangan dan Gizi Universitas Gadjah Mada, Yogyakarta,

Kardono LBS. 2003. Kajian kandungan kimia mahkota dewa (Phaleria macrocarpa) dalam prosiding seminar sehari mahkota dewa. Jakarta: puslitbang Farmasi dan obat tradisional bahan penelitian dan pengembangan kesehatan Departemen Kesehatan.

Kartika, B., P, Hastuti, W. Supartono 1987. Pedoman Uji Indrawi Bahan Pangan, Penerbit Pusat Publishing Compang, Inc, Wastport Connetticut.

Kumalaningsih S. dan Suprayogi 2006. Tamarillo ( Terung Belanda). Turbus Agrisarana Surabaya.

Lisdawati, V, 2002. Buah Mahkota Dewa Toksisitas, Efek Anti Oksidan Dan Efek Anti Kanker Berdasarkan Uji Penapisan 
Farmakologi. http://www. Mahkota dewa. Comlindi/info /makaahlvivi20 1002.htm, diakses pad 30 april 2007.

Lisdawati, V, Kardono LBS. 2006. Aktivitas antioksidan dari berbagai fraksi ekstrak daging buah dan kulit biji mahkota dewa (Phaleria macrocarpa). Media litbang kesehatan 16:4.

Rahmawan, W. S. 2006. Pemanfaatan Potensi Tepung Ubi Jalar dan Pati Garut Sebagai Bahan Substitusi Tepung Terigu Dalam Pembuatan Cookies Yang Diperkaya Isolat Protein Kedelai Untuk Intervesi Gizi. Skripsi Fakultas Pertanian Program Studi Gizi Masyarakat Dan Sumberdaya Keluarga. Institut Pertanian Bogor.Bogor.

Rampengan, $\quad$ V. , J, Pontoh dan D. T . Sembal, 1985.

Dasar-dasar Pengawetan Mutu Pangan. Badan Kerja Sarna Perguruan Tinggi Negeri Indonesia Bagian Timur, Makasar.

Saleh I. 2007. Aktivitas Antioksidan Daging Buah dan Daun Mahkota Dewa Berdasarkan Pengukuran Kapasitas Reduksi $\mathrm{Ce}(\mathrm{IV})$ [Skripsi]. Bogor: Fakultas Matematika Dan Pengetahuan Alam, institute Pertanian Bogor.

Satuhu, S., 1996. Penanganan dan Pengolahan Buah. Penebar Swadaya, Jakarta

Shalahuddin 1. 2005. Efek Antihiparlikemik Ekstrak Air
Buah Mahkota Dewa Pada Tikus Diabetes Yang Di Induksi Streptolosin [Skripsi]. Bogor : Fakultas Matematika Dan Pengetahuan Alam. Institute Pertanian Bogor.

Sudarmadji, S., Haryono, B. dan Suhardi. 1997. Prosedur analisa bahan makanan dan pertanian . Liberty, Y ogyakarta. Suyitno. 1989. Petunjuk Laboratorium Rekayasa Pangan. Pus at Antara Fakultas Pangan dan Gizi Universitas Gajah mada. Yogyakarta.

Soekarto. 1990. Penilaian Organoleptik Untuk Industri Pangan Dan Hasil Pertanian. Bhratara Karya Aksara. Jakarta.

Syarief, R. dan Halid, H. 1991. Teknologi Penyimpanan Pangan. Penerbit Arcan.Iakarta. Winarno, F.G., dan Fardiaz, 1997. Kimia Pangan dan Gizi, PT. Gramedia, Jakarta.

Winarno, F.G., S. Fardiaz dan D. Fardiaz, 1998. Pengantar Teknologi Pangan Gramedia, Jakarta.

Winamo. $1989 . \quad$ Sterilisasi Komersial Produk Pangan. Jakarta: PT Gramedia Pustaka Utama.

Winarno, WP., 2003. Mahkota dewa : Budidaya dan Pemanfaatan Untuk Obat. Jakarta: Penebar Swadaya.

Winarno, F.G., 2004.Kimia Pangan dan Gizi. Gramedia Pustaka Utama. Jakarta. 